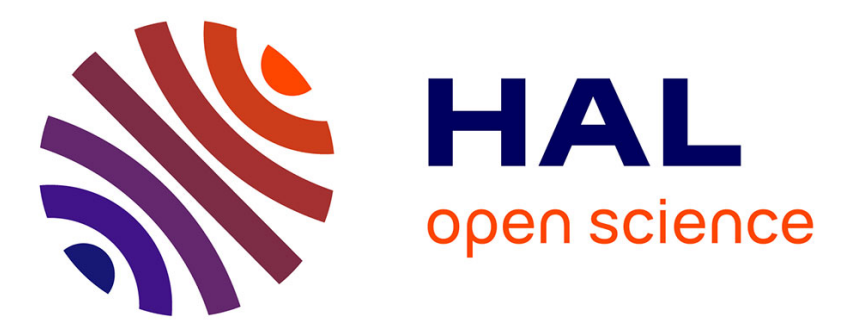

\title{
Pre--neurosurgical detection of cerebral motor areas by functional MRI: Comparison between Blood Oxygenation Level (BOLD) and functional Arterial Spin Labeling (fASL) techniques
}

Christophe Paya, Isabelle Corouge, Elise Bannier, Jean-Christophe Gentric, Jean-Christophe Ferré

\section{To cite this version:}

Christophe Paya, Isabelle Corouge, Elise Bannier, Jean-Christophe Gentric, Jean-Christophe Ferré. Pre--neurosurgical detection of cerebral motor areas by functional MRI: Comparison between Blood Oxygenation Level (BOLD) and functional Arterial Spin Labeling (fASL) techniques. SFNR 2018 45ème Congrès de la Société Française de Neuroradiologie, Mar 2018, Paris, France. pp.1-2. inserm01963573

\section{HAL Id: inserm-01963573 https://www.hal.inserm.fr/inserm-01963573}

Submitted on 21 Dec 2018

HAL is a multi-disciplinary open access archive for the deposit and dissemination of scientific research documents, whether they are published or not. The documents may come from teaching and research institutions in France or abroad, or from public or private research centers.
L'archive ouverte pluridisciplinaire HAL, est destinée au dépôt et à la diffusion de documents scientifiques de niveau recherche, publiés ou non, émanant des établissements d'enseignement et de recherche français ou étrangers, des laboratoires publics ou privés. 


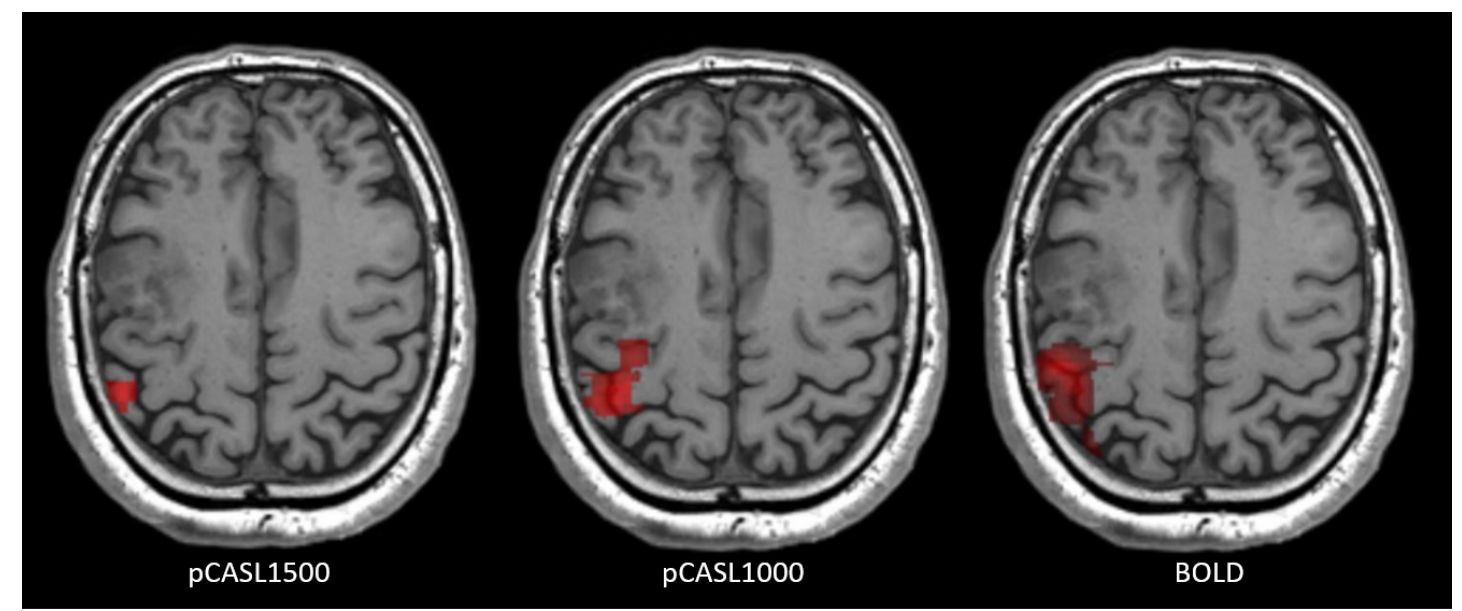

Figure 1. Motors maps obtained on the same subject for pCASL1500, pCASL1000 and BOLD acquisitions, using General Linear Model and massively univariate statistical analysis with a 5\% Family Wise Error Rate.

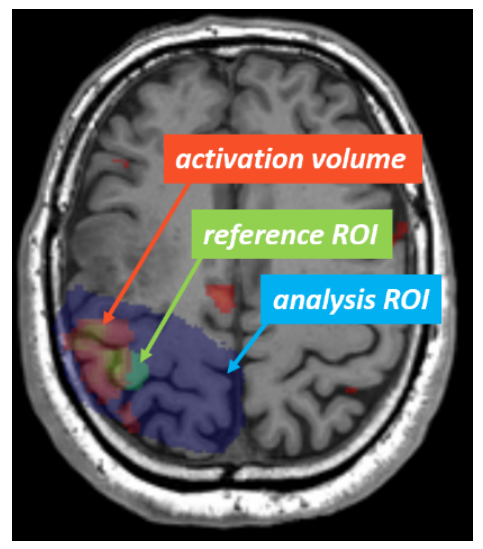

Figure 2. Illustration of analysis $\mathrm{ROI}$, reference $\mathrm{ROI}$ and activation volume

Pre-neurosurgical detection of cerebral motor areas by functional MRI: Comparison between Blood Oxygenation Level (BOLD) and functional Arterial Spin Labeling (fASL) techniques.

C. Paya ${ }^{a *}$, I. Corouge ${ }^{b}$, E. Bannier ${ }^{b}$, J.-C. Gentric ${ }^{c}$, J.-C. Ferré ${ }^{a b}$

a CHU Rennes, Imagerie médicale et radiodiagnostic, Hopital Pontchaillou, Rennes, France b Université de Rennes, CNRS, Inria, Inserm, VISAGES - ERL U 1228, Rennes, France

c CHU Brest, Radiologie et Imagerie médicale, Hopital de la Cavale Blanche, Brest, France

\section{Goal}

BOLD MRI is well implanted in clinical practice and remains the reference technique for activation mapping in surgical planning for primitive brain tumor. Our goal was to perform qualitative and quantitative evaluation of $\mathrm{fASL}$ and BOLD in Primitive Motor Area (PMA) detection in this clinical context.

\section{Materials and methods}

BOLD and pseudo-continuous ASL with Post Labeling Delay of 1500ms (pCASL1500) and 1000ms (pCASL1000) acquisitions were performed on 21 subjects (4 healthy volunteers and 17 patients scheduled to neurosurgery), at 3T, using a block-design motor paradigm. Motor maps (figure 1) were 
produced using General Linear Model with a massively univariate analysis and a 5\% Family Wise Error Rate. Visual detection rate was defined by the rate of subjects, whose motor maps visually matched the PMA defined by anatomical landmarks. PMA detection sensitivity and specificity were computed using manual segmentation of PMA as a reference Region Of Interest (ROI) and inside an analysis ROI (figure 2) to overcome inter-patient variability in other motor area activation. Activation volumes obtained from BOLD and fASL were also compared.

\section{Results}

Visual detection rates were $47,6 \%$ for pCASL1500, $85,7 \%$ for pCASL1000 and $95,3 \%$ for BOLD. Detection sensitivity of PMA was significantly higher in BOLD $(81 \pm 26 \%)$ compared to pCASL1500 $(19 \pm 32 \%, p<0,001)$ and $p C A S L 1000(50,5 \pm 36 \%, p=0,013)$. Detection specificity was significantly higher in pCASL1500 $(94 \pm 8 \%, p=0,001)$ and pCASL1000 $(93,2 \pm 6 \%, p=0,01)$ compared to BOLD $(73,1 \pm 16 \%)$. However, activation volumes were higher in $\operatorname{BOLD}(11,81 \pm 8 \mathrm{ml}, \mathrm{p}<0,0001)$ compared to $\mathrm{pCASL1500}$ $(1,25 \pm 2 \mathrm{ml})$ and pCASL1000 $(2,74 \pm 2 \mathrm{ml})$. Considering a reference ROI volume of $1,14 \pm 0,5 \mathrm{ml}$, the PMA's volume estimation error would be higher in $\operatorname{BOLD}(p<0,001)$.

\section{Conclusion}

fASL is able to detect PMA in pre-neurosurgical context. Despite a lower PMA detection sensitivity than BOLD, fASL offered a higher specificity. PCASL1500 had a low visual detection rate of PMA while pCASL1000 should be further explored for a potential clinical use.

* auteur correspondant : C. Paya (paya.christophe@gmail.com)

Les auteurs déclarent n'avoir aucun conflit d'intérêt.

(1) Raoult H, Petr J, Bannier E, Stamm A, Gauvrit J-Y, Barillot C, et al. Arterial spin labeling for motor activation mapping at 3T with a 32-channel coil: reproducibility and spatial accuracy in comparison with BOLD fMRI. Neuroimage.2011;58(1):157 67. 